\title{
Determination of eco-efficiency level of solid waste management of polypropylene cloth on motorcycle tire industry in Cileungsi (West Java)
}

\author{
Bagus Priambodo ${ }^{1, *}$ and Djoko M. Hartono ${ }^{2}$ \\ ${ }^{1}$ School of Environmental Science, Universitas Indonesia. UI Salemba Campus. Central Jakarta \\ 10430. Indonesia. \\ ${ }^{2}$ Department of Environmental Engineering, Faculty of Engineering, Universitas Indonesia. UI Depok \\ Campus. West Java 16424. Indonesia.
}

\begin{abstract}
Sustainability is now accepted by all stakeholders as a guiding principle for both public policy making and corporate strategies. However, the biggest challenges are still in the real and substantial implementation of the sustainability concept. The Motorcycle Tire Manufacturing Industry produces a by-product in the form of solid waste Polypropylene Fabric which is produced from one of its production processes, namely the Calendering process. Therefore, efforts need to be made to manage the waste resulting from the production process to become something more valuable so that a better level of eco-efficiency can be obtained. The purpose of this study is to determine the level of eco-efficiency of Polypropylene Fabric solid waste treatment produced from the calendering process and provide recommendations in an effort to improve the value of eco-efficiency. The quantitative method is used to calculate the efficiency of polypropylene fabric solid waste management that can still be taken from the waste. Based on the results of laboratory calculations and checks it was found that there was an eco-efficiency value of $30 \%$ for the reuse of waste polypropylene cloth and there were economic benefits of Rp. $355,877,264$ in 2018 (based on forecasting the addition of waste in the future).
\end{abstract}

\section{Introduction}

Sustainability is nowadays accepted by all stakeholders as a guiding principle for both public policy making and corporate strategies. However, the biggest challenge for most organizations remains in the real and substantial implementation of the sustainability concept. The core of the implementation challenge is the question, how sustainability performance can be measured, especially for products and processes. The global society has undergone a paradigm shift from environmental protection towards sustainability [1]. Sustainability does not only focus on the environmental impact, it rather consists of the

${ }^{*}$ Corresponding author: baguspriambodo23@gmail.com 
three dimensions "environment", "economy" and "social well-being", for which society needs to find a balance or even an optimum $[1,2]$.

The concept of sustainable development was first described in 1987 by the World Commission on Environment and Development under the leadership of the former Norwegian Prime Minister Brundtland [2]. It describes a development that is capable to cover today's needs for an intact environment, social justice and economic prosperity, without limiting the ability of future generations to meet their needs. The preservation of the natural environment is a prerequisite for a well-functioning economy and social justice. Thus it is necessary to bring the three pillars of sustainability-environment, economy, social well-being in harmony in all areas of life, both nationally and internationally.

Over the last decades numerous assessment methods and tools for environmental and sustainability performance have been developed. They are grouped in Figure 1 according to an adapted pyramid of needs from Maslow [4]. While the original pyramid of Maslow has the basic physiological needs like food and breathing at the bottom, followed by safety needs, love and belonging, esteem until self-actualization at the very top, the adapted version starts with the basic approach of Life Cycle Thinking, followed by single-issue methods like Carbon or Water Footprinting, Life Cycle Assessment (LCA), Resource or Eco-efficiency Assessment up to Life Cycle Sustainability Assessment (LCSA) at the top of the pyramid (see Figure 1).



Fig. 1. Adaptation of Maslow's pyramid of human needs for life cycle based environmental and sustainability assessment approaches.

Life Cycle Thinking represents the basic concept of considering the whole product system life cycle from the "cradle to the grave". It aims to prevent individual parts of the life-cycle from being addressed in a way that just results in the environmental burden being shifted to another part. Life Cycle Thinking has for example been addressed as one of the five key principles of the Integrated Product Policy of the European Union [5]. Life Cycle Thinking is a qualitative concept. With the next level in the pyramid the approaches start to be quantitative. More recently, evaluation approaches for single environmental issues like Carbon Footprinting [6] and Water Footprinting [7] have received considerable attention. They use the life cycle concept but address only one environmental impact, i.e., climate change or water scarcity. The next level is represented by Life Cycle Assessment (LCA). LCA is built around the principle of comprehensiveness and therefore aims to address all environmental interventions - not just one [8]. LCA is a well established environmental management tool for which international standards are available in their second generation $[9,10]$. With the next level, the purely environmental focus is left and economic aspects 
come into play. Both resource efficiency and eco-efficiency assessment approaches combine environmental indicators with economic indicators. On top of the pyramid, the last missing sustainability dimension, i.e., the social one, is added to the other dimensions as part of a full life cycle based sustainability assessment.

The increasing public demand for a number of goods and services encourages the growth of various industrial activities that produce goods and services to meet the needs of these communities. This will have a positive impact on improving economic conditions, but on the other hand causes various negative impacts because industrial activities also produce non-product output or non-product output in the form of pollutants. Which includes NPO or non-product output is in the form of materials, energy and water used in the production process, but does not end up being the final product. Outputs not products can also be said as activities that do not produce added value, and consequently produce unnecessary costs for the company. In addition, outputs not products in the form of pollutants often lead to a condition that has a negative impact on the community and the environment [11].

Efforts to manage pollution carried out by industry have been carried out after the waste is formed (end of pipe treatment). This can not solve environmental problems completely, because it has the risk of removing pollutants from a media to other media. From an economic standpoint, waste treatment with this approach is less profitable, because it requires a large investment cost to build a good waste treatment system. A motorcycle is one of the common vehicles found. The use of motorbikes has increased every year seen since 2015. According to the Central Bureau of Statistics, the increase in motorcycle users in Indonesia increased by $81.5 \%$, followed by passenger cars with $11.11 \%$, then goods cars $5.45 \%$, and bus cars $1.99 \%$. (http://www.bps.go.id, accessed October 11, 2017). With the increasing number of motorcycle users in Indonesia, the motorcycle tire maker industry was affected by the soaring sales of motorcycle tires (Tire). The increasing demand for motorcycle tires, forced the motorcycle tire maker industry to compete to increase efficiency and accelerate in every process without reducing the quality of the products produced.

PT. Ban $\mathrm{X}$ is a company engaged in the manufacture of outside tires (tires) and motorcycle tires (Tube). This company is a subsidiary of PT. Motor X, which was founded in 1991 with the product brands produced, namely XX and YY. Therefore an effective waste minimization strategy is needed and can reduce production costs so that it will improve efficiency, product quality and good relations with the community and improve environmental quality. The principle of efficiency here is to use less energy and resources through better performance, so as to reduce the amount of waste and pollution to the environment. One effort that can be done is through environmental management planning with the implementation of eco-efficiency. The implementation of eco-efficiency is almost the same as the concept of clean production, where environmental management is carried out in the direction of pollution prevention which reduces the formation of waste, starting from the selection of raw materials to the products produced. The difference is in its orientation, where eco-efficiency is oriented towards increasing economic efficiency through reducing the use of natural resources and energy. While clean production is oriented towards pollution prevention strategies. Eco-efficiency strategy is a new paradigm in the management of voluntary environmental pollution, by taking steps to minimize the use of raw materials, energy and water to improve production efficiency. The use of this strategy can be easily implemented by the company because it is only through simple steps and with a relatively small investment cost. So that the problem of environmental pollution, especially for industry, is no longer identical to the additional expenditure for high waste treatment costs. One of the eco-efficiency tools is good housekeeping (GHK), which is related to a number of practical steps based on common sense that can be immediately taken by business entities and on their own initiative to improve operating performance, 
improve internal learning procedures organization and improve occupational safety and health [12].

The benefits obtained by the company from the implementation of this good housekeeping are in the form of cost savings, better environmental performance and the existence of learning within the company's organization, so that it will help improve the company's performance in the long run. The study of the production process and the technical, economic and environmental studies of the implementation of eco-efficiency in the deinking plant unit, PT. Ban X is carried out to identify the extent of the application / application of eco-efficiency that has been carried out by PT. Ban X and the benefits obtained, both economically and environmentally, as well as providing recommendations and advice to companies that can be used as alternative policies relating to the implementation of eco-efficiency and good internal governance.

\section{Methods}

This study uses a quantitative approach. Quantitative approach is an approach that is carried out using several variables with certain frequencies and clear measurements and using statistical measurement tools. This research uses quantitative methods. The quantitative method is used to calculate the eco-efficiency analysis in the management of polypropylene fabric solid waste management to calculate the utilization of the waste and the economic value that can still be taken from the waste.

\section{Results and discussion}

Table 1 shows the amount of waste on polypropylene fabric based on data from 2013-2017.

Table 1. Pantai Bahagia Village Mangrove Area.

\begin{tabular}{|l|c|c|c|}
\hline \multicolumn{1}{|c|}{ Period } & $\begin{array}{c}\text { Waste } \\
\text { (Un/Year) }\end{array}$ & Weigh (Kg./Un) & $\begin{array}{c}\text { Total Weight } \\
\text { (Kg.) }\end{array}$ \\
\hline 2013 & 55 & 163 & 8,965 \\
\hline 2014 & 39 & 163 & 6,357 \\
\hline 2015 & 31 & 163 & 5,053 \\
\hline 2016 & 43 & 163 & 7,009 \\
\hline 2017 & 45 & 163 & 7,317 \\
\hline
\end{tabular}

The level of eco-efficiency of processing Polypropylene Fabric solid waste produced from the calendering process at PT. Ban X is done by looking at the potential utilization of waste based on waste forecasting data that will be produced by PT. Ban X during 20182022 listed in table 2. Forecasting is done using the Single Moving Average method. Furthermore, based on the results of laboratory tests and checking in the field, it was found that there was an optimization of the reuse of waste by $30 \%$. Then it can be seen in table 3 the economic value of the utilization of the waste. Optimization carried out on solid waste 
Polypropylene Fabric produced from the calendaring process will be utilized as a production facility in the Calendering Insulation process.

Table 2. Degree of community participation in mangrove management in Pantai Bahagia Village.

\begin{tabular}{|c|c|c|c|c|c|c|}
\hline Period & $\begin{array}{c}\text { Waste } \\
\text { Forecast } \\
\text { (Un/Year) } \\
\text { (A) }\end{array}$ & $\begin{array}{c}\text { Weight } \\
\text { (Kg./Un) } \\
\text { (B) }\end{array}$ & $\begin{array}{c}\text { Total Weight } \\
\text { (Kg.) } \\
(\mathbf{C}=\mathbf{A} * \mathbf{B})\end{array}$ & $\begin{array}{c}\text { Utilization } \\
\text { Potentially } \\
\text { (\%) } \\
\text { (D) }\end{array}$ & $\begin{array}{c}\text { Total Reduce } \\
(\text { Kg. }) \\
(\mathbf{E}=\mathbf{C} * \mathbf{D})\end{array}$ & $\begin{array}{c}\text { Grand } \\
\text { Total } \\
\text { Weight } \\
(\text { Kg. }) \\
(\mathbf{F}= \\
\left.\mathbf{C}^{*} \mathbf{E}\right)\end{array}$ \\
\hline 2018 & 47 & 163 & 7,734 & $30 \%$ & 2,320 & 5,414 \\
\hline 2019 & 49 & 163 & 7,938 & $30 \%$ & 2,382 & 5,557 \\
\hline 2020 & 50 & 163 & 8,143 & $30 \%$ & 2,443 & 5,700 \\
\hline 2021 & 51 & 163 & 8,347 & $30 \%$ & 2,504 & 5,843 \\
\hline 2022 & 52 & 163 & 8,551 & $30 \%$ & 2,565 & 5,986 \\
\hline
\end{tabular}

Table 2. Degree of community participation in mangrove management in Pantai Bahagia Village.

\begin{tabular}{|c|c|c|c|}
\hline Period & $\begin{array}{c}\text { Total Reduce } \\
\text { (Kg.) }\end{array}$ & Save Cost (Rp./Kg.) & $\begin{array}{c}\text { Total Save Cost } \\
\text { (Rp.) }\end{array}$ \\
\hline 2018 & 2,320 & 153,374 & $355,877,264$ \\
\hline 2019 & 2,382 & 153,374 & $365,268,239$ \\
\hline 2020 & 2,443 & 153,374 & $374,659,213$ \\
\hline 2021 & 2,504 & 153,374 & $384,050,188$ \\
\hline 2022 & 2,565 & 153,374 & $393,441,162$ \\
\hline
\end{tabular}

\section{Conclusions}

Based on the results of laboratory calculations and checks it was found that there was an eco-efficiency value of $30 \%$ for the reuse of waste polypropylene cloth and there were economic benefits of Rp. 355,877,264 in 2018 (based on forecasting the addition of waste in the future).

\section{Acknowledgements}

The author would like to thank Prof. Djoko M. Hartono and Universitas Indonesia for support our research.

\section{References}

1. K.W. Brand, Politik der Nachhaltigkeit (Berlin, Germany, 2002)

2. G.H. Bruntland, Our Common Future (Oxford University Press, Oxford, 1987)

3. F. Rubik, Integrierte Produktpolitik (Metropolis, Germany, 2002)

4. A.H. Maslow, Psychol. Rev. 50, 370-396 (1943)

5. Communication on Integrated Product Policy (European Commission, Brussels, Belgium, 2003)

6. M. Finkbeiner, Int. J. Life Cycle Assess. 14, 91-94 (2009) 
7. M. Berger, M. Finkbeiner. Sustainability 2, 919-944 (2010)

8. M. Finkbeiner, A. Inaba, R.B.H. Tan, K. Christiansen, H.J. Klüppel, Int. J. Life Cycle Assess. 11, 80-85 (2006)

9. Environmental Management-Life Cycle Assessment-Principles and Framework (ISO 14040) (ISO, Geneva, 2006)

10. Environmental Management-Life Cycle Assessment—Requirements and Guidelines (ISO 14044) (ISO, Geneva, 2006)

11. Nuryakin, Studi Evaluasi Perencanaan Pengelolaan Lingkungan melalui Pendekatan Ekoefisiensi (Studi Kasus pada Unit Dainking Plant, PT. Kertas Leces, Probolinggo) (UNDIP. Semarang, 2007)

12. Purwanto, Jurnal Ilmu Lingkungan 03 (2005) 